\title{
From 1999 to 2019: 20 years of European debate, development, and achievements
}

\author{
Maria Sticchi Damiani* \\ doi: http://dx.doi.org/10.18543/tjhe-6(2)-2019pp51-71
}

Received: 03-04-2019

Accepted: 02-05-2019

\begin{abstract}
This paper suggests that, although the Bologna process officially began in the late 1990 s, the conditions that made it possible had already been created in the previous decade through the growing practice of international academic cooperation, mainly triggered by EU inter-institutional programmes. As the need for structural reforms in some higher education systems became more evident, in 1999 the Ministers of Education of 29 European countries gathered in Bologna to start a process of voluntary convergence of their systems with the objective of creating a European Higher Education Area. In the last 20 years the participating governments (now 48), with the support of international organizations and major stakeholders, have jointly developed a common framework of principles, actions, policies and tools. Accordingly, different types of structural reforms have taken place in the various countries. At present, however, implementation of the key commitments full adoption of the three-cycle structure and ECTS, of the Lisbon recognition convention and the Diploma supplement, and of QA systems based on the European standards and guidelines - is still uneven in the EHEA and a peer-support approach was adopted by the ministers last year. Concerning the implementation issue, this paper raises two sets of questions. First: to what extent have the structural reforms implemented by the governments really affected grassroots educational activities? How deeply have the underlying principles - like student-centred learning - been implemented in actual programme design and everyday teaching/learning practice? Second: although inspired by the same basic principles, are EHEA-induced reforms actually being implemented consistently throughout European countries and
\end{abstract}

* Maria Sticchi Damiani (msticchi@gmail.com) is a former professor of English at the Free International University of Social Studies (LUISS) in Rome, where she served as Head of the Department of Modern Languages and Rector's delegate for International Relations.

More information about the author is available at the end of this article.

Acknowledgements: I wish to thank my European colleagues and friends for what I learned from them in the past 30 years. Special thanks to a special friend, Kathy Isaacs. 
institutions? Deeper involvement and more international coordination of European academics is advocated in the paper, in order to face these challenges and consolidate the EHEA in the years to come.

Key words: Europe; HE systems; HE institutions; cooperation; convergence; reforms; implementation; cultural change.

The Bologna Declaration, ${ }^{1}$ signed in 1999 by the Education Ministers of 29 European countries, marks the official start of the process which led to the creation of the European Higher Education Area in 2010 and to its consolidation in the following years. The term "Bologna process" is still used to describe the series of collective actions that have gradually designed a new and distinctive profile of European higher education. This trajectory is certainly the result of a chronological sequence of events, but can also be approached in conceptual terms by identifying the specific features which coexisted and overlapped during the process, although one or some of them seemed to prevail at each stage. To exemplify, let us consider the most significant steps, or phases, in the Bologna process.

\section{Cooperation}

Although the Bologna process officially began in the late 1990s, we suggest that the conditions that made it possible had already been created in the previous decade through the growing practice of international academic cooperation.

In 1987, the European Commission launched the Erasmus programme to promote cooperation among EU higher education institutions. These were encouraged to make agreements enabling them to exchange students for an academic year or a term and give them full recognition for studies done abroad.

In 1988, moreover, 388 Rectors and Heads of Universities, from all over Europe and beyond, gathered in Bologna for the $900^{\text {th }}$ anniversary of the University of Bologna. By signing the Magna Charta Universitatum, ${ }^{2}$ they

1 “The European Higher Education Area: The Bologna Declaration, 19 June 1999," http://www.ehea.info/Upload/document/ministerial_declarations/1999_Bologna_Declaration_ English_553028.pdf.

2 "Magna Charta Universitatum" (Bologna, 18 September 1988), http://www.magnacharta.org/resources/files/the-magna-charta/english. 
proclaimed the fundamental academic principles "which must now and always, support the vocation of universities". For the attainment of such goals they advocated "the exchange of information and documentation, and frequent joint projects for the advancement of learning"; and, "as in the earliest years of their history", they encouraged mobility of teachers and students.

Starting in 1989, the European Credit Transfer System (ECTS) was developed by the European Commission as a pilot project involving groups of European institutions that experimented with student mobility in specific subject areas to design a system for the academic recognition of the periods of study abroad.

Within Erasmus networks, academic staff had the opportunity to visit institutions in other European countries, in order to teach, monitor their students abroad and develop joint curricula with colleagues in those institutions. Thematic networks for various subject and thematic areas were also set up from the mid1990s: there, groups of European academics from all eligible countries worked together to map the diverse national approaches and to develop a Europe-wide vision of how disciplines were studied and taught. With the gradual expansion of the countries coming into the Erasmus programme, and eventually into the EU, cooperation extended to new partner institutions and participants could experience the rich diversity of a broader Europe.

The participation of higher education institutions in the Erasmus programme was voluntary. Especially at the beginning, it relied mostly on the initiative and goodwill of individuals (teachers and administrators), who made the first contacts with colleagues abroad, developed good personal and professional relations with them, and set up discipline-based networks of institutions. Student exchanges were handled through meetings and correspondence, by mail and fax, and problems were solved through mutual trust and confidence. In those years, the people involved in student exchanges learned how to work with colleagues from different countries and different cultures - often using different languages - and realised how rewarding it was to be engaged in international cooperation activities.

Students responded enthusiastically to the new opportunity to spend a period abroad in another university, with the recognition of their studies. Since the places available were initially limited, the students selected were usually highly qualified and received much individual attention from the coordinators of the home and host institutions. Their desire to have a personal and cultural experience abroad quickly involved them in the pioneering atmosphere of those early years, when everything was new and had to be organised from scratch. 
Due to the new requirements of EU programmes, the management of international activities gradually moved from individual academics to the central administration, and higher education institutions made some organisational changes to meet the growing demands of international cooperation - although the initiative largely continued to be in the hands of motivated individuals. In the 1990s, new offices, specifically concerned with international activities and requiring new professional skills, were set up; transparent student selection procedures were adopted; and the academics responsible for student mobility were asked to handle the recognition of studies abroad using a well-grounded and consistent approach.

Even though the diversity of partner institutions was accepted and explored with curiosity, the difficulties of moving students from one higher education system to another, and back, were also clearly perceived. It was often hard to identify the most appropriate study programme for a student in a host institution, where the degree structure was different and study programmes were organized in a different way; it was also difficult to recognize the outcomes of these studies and incorporate them into the home programme, when the course descriptions of the host institution were inadequate: decisions were mainly based on personal contacts and required the utmost flexibility.

\section{Convergence}

Meanwhile, in most European countries higher education had gradually expanded its target from the elites to broader social strata, and some governments had become aware that this transformation required a radical reform of their higher education systems. These governments also realized that, given the inter-institutional cooperation already going on across Europe, it would be useful to develop such reforms together, laying the foundations of a European higher education area where such cooperation could take place more easily. Also because of the impulse of their institutions and Rectors' conferences, they decided to act together and started a process of voluntary convergence of their systems. The first joint declaration ${ }^{3}$ was signed by the Ministers of Education of France, Italy, Germany and the United Kingdom at the Sorbonne on May 25, 1998, eleven years after the beginning of the

3 "Joint declaration on harmonisation of the architecture of the European higher education system" (Paris, the Sorbonne, 25 May 1998), http://www.ehea.info/media.ehea.info/ file/1998_Sorbonne/61/2/1998_Sorbonne_Declaration_English_552612.pdf. 
Erasmus programme. This government-driven convergence process, based on inter-governmental agreements, easily overlapped with - and greatly contributed to - the EU-driven cooperation activities based on interinstitutional agreements. In fact, the countries that were involved in the process clearly stated that their main goal in creating a European higher education area was promoting the mobility of students and graduates - which was also at the core of the cooperation programmes.

About a year later (June 19, 1999) the Ministers of Education of 29 European countries $(15 \mathrm{EU}+14)$ gathered in Bologna to sign the Bologna Declaration, ${ }^{4}$ in which they formally expressed their support for the common goal of establishing a European Higher Education Area by the year 2010 and committed themselves to coordinating their policies in order to reach common objectives. In the following years other European countries joined the process, up to the present 48 members. Their eligibility was based on their being part of the European region, as defined by the Council of Europe (CoE), and having signed the CoE European Cultural Convention.

From the very beginning a support structure, called Bologna Follow-Up Group (BFUG), was set up to organise further meetings of the Ministers every two years and coordinate the activities taking place in between them. The BFUG included representatives of the participating countries as full members, while several international organizations and the representatives of major stakeholders in higher education were invited to join in as consultative members, to expand the scope of the initiative. The European Commission first joined the BFUG with a consultative role, but soon became a full member, offering a valuable contribution of experience in European educational programmes and funding several activities within the process. After each meeting, held in a different European location, the Ministers issued a joint communiqué to state the progress made in the convergence process and to define new objectives. In each semester, the BFUG was cochaired by the country holding the EU presidency and a non-EU country designated by applying an alphabetical order. Secretariat services were provided by the country that had committed itself to hosting the following Ministerial Conference.

As planned, in 2010 the European Higher Education Area (EHEA) was officially launched, and a second formal declaration - the Budapest-Vienna Declaration was signed by the Ministers.

4 “The European Higher Education Area: The Bologna Declaration, 19 June 1999," http:// www.ehea.info/Upload/document/ministerial_declarations/1999_Bologna_Declaration_ English_553028.pdf. 
Last year, the $20^{\text {th }}$ anniversary of the first joint declaration was celebrated in Paris at the Sorbonne. In the current year, 2019, the Bologna declaration will be celebrated in the University where that document was originally signed. Therefore, it could be the right time to look back at this long and articulated process and try to provide a more general picture of it. Accordingly, we identify four main areas of convergence that have largely shaped the EHEA: shared principles, parallel actions/structural reforms, agreed policies and common tools.

\section{II.1. Principles}

Three basic principles of the EHEA are neatly expressed by the European Ministers in the Budapest-Vienna Declaration (March 2010). ${ }^{5}$ They concern:

- Their own responsibility vis-à-vis higher education: "We, the Ministers, reaffirm that higher education is a public responsibility. We commit ourselves, notwithstanding these difficult economic times, to ensuring that higher education institutions have the necessary resources within a framework established and overseen by public authorities."

- The responsibility of institutions: "We, the Ministers, recommit to academic freedom as well as autonomy and accountability of higher education as principles of the EHEA and underline the role the higher education institutions play in fostering peaceful democratic societies and strengthening social cohesion."

- The role of the academic community: "We acknowledge the key role of the academic community - institutional leaders, teachers, researchers, administrative staff and students - in making the EHEA a reality, providing the learners with the opportunity to acquire knowledge, skills and competences furthering their careers and lives as democratic citizens as well as their personal development."

Another key principle concerns the commitment to a learner-centred approach in education. This principle appears in several documents but is more comprehensively defined in the ECTS Users' Guide, ${ }^{6}$ which was formally

5 "Budapest-Vienna Declaration on the European Higher Education Area" (12 March 2010), http://www.ehea.info/media.ehea.info/file/2010_Budapest_Vienna/64/0/BudapestVienna_Declaration_598640.pdf.

6 "ECTS Users' Guide" (Publications of the European Union, 2015), https://ec.europa.eu/ education/ects/users-guide/docs/ects-users-guide_en.pdf. 
adopted by the Ministers in 2015 in Yerevan after a careful revision process. According to the Guide, study programmes designed using ECTS credits are based on expected learning outcomes, which are defined as "statements of what the individual knows, understands and is able to do on completion of a learning process"; and on the estimated learning time (workload), which is defined as "the time the individual typically needs to complete all learning activities, such as lectures, seminars, projects, practical work, work placements and individual study, required to achieve the defined learning outcomes in formal learning environments". Moreover, the Guide suggests that study programmes should be delivered giving learners sufficient choice of content, mode and pace of learning, helping them to build on their individual learning styles and experiences, using effective teaching/learning methods, and providing learners with adequate educational guidance and facilities.

\section{II.2. Actions}

The main actions jointly decided by the Ministers, to be implemented in the single countries as structural reforms, concern the adoption of:

- A common degree structure, originally based on two main cycles and soon expanded to include the doctoral level as a third cycle (Berlin Communiqué, September 20037): this three-tier structure was well described in the document "A Framework for Qualifications of the EHEA" (adopted by the Ministers in 2005 in Bergen), where the cycles are defined through agreed ranges of credits and agreed general learning outcomes, generally referred to as Dublin Descriptors. In the last Ministers' meeting (Paris, 2018) an optional short cycle was also included in the European framework.

- Common quality assurance procedures, as described in another official document, "European Standards and Guidelines for Quality Assurance in the EHEA" (first adopted in 2005 and revised in 2015), ${ }^{9}$ that defines

7 "Realising the European Higher Education Area. Communiqué of the Conference of Ministers responsible for Higher Education" (Berlin, 19 September 2003), http://www.ehea.info/ Upload/document/ministerial_declarations/2003_Berlin_Communique_English_577284.pdf.

8 "A Framework for Qualifications of the European Higher Education Area" (Ministry of Science, Technology and Innovation, Copenhagen, 2005), http://ecahe.eu/w/images/7/76/A_ Framework_for_Qualifications_for_the_European_Higher_Education_Area.pdf.

9 "Standards and Guidelines for Quality Assurance in the European Higher Education Area (ESG)" (Brussels, Belgium, 2015), https://enqa.eu/wp-content/uploads/2015/11/ 
common European quality standards and offers appropriate guidelines for the development of internal and external quality assurance in institutions, as well as for the quality of the QA agencies themselves.

- Common recognition procedures, as described in the "Lisbon Recognition Convention" 10 (1997), already signed by over 50 European and non-European countries, which provided basic principles and clear procedures for the recognition of qualifications and periods of study abroad.

On the whole, the three documents mentioned above provide practical guidance for constructing the backbone of the EHEA: a common degree structure and credit system, with common quality standards and common recognition procedures, which would eventually allow for the smooth mobility of students and graduates in the area.

\section{II.3. Policies}

The policies agreed by the EHEA ministers were mainly intended as an indication to each government to steer its national policies towards common goals. With the exception of mobility, no quantitative benchmark was established for EHEA policies: governments were just invited to work in parallel towards the achievement of the common goals and report on the progress made in each country.

- Mobility came first, as one of the objectives mentioned in the Bologna Declaration (1999), and was steadily viewed over time as the "hallmark of the EHEA": countries were urged to increase student mobility, to ensure its quality and diversify its types and scope. Only for student mobility the Ministers established a European benchmark: in 2020 at least $20 \%$ of those graduating in the EHEA should have had a study or a training experience abroad (Leuven Communiqué, April 2009 ${ }^{11}$ ).

ESG_2015.pdf.

10 "Convention on the Recognition of Qualifications concerning Higher Education in the European Region” (Council of Europe, Lisbon, 11 April 1997), https://www.coe.int/en/web/ conventions/full-list/-/conventions/rms/090000168007f2c7.

11 "The Bologna Process 2020: The European higher Education Area in the new decade. Communiqué of the Conference of European Ministers Responsible for Higher Education" (Leuven and Louvain-la-Neuve, 28-29 April 2009), http://www.ehea.info/Upload/document/ ministerial_declarations/Leuven_Louvain_la_Neuve_Communique_April_2009_595061.pdf 
- Lifelong Learning ( $L L L)$ was brought in at an early stage, as the Ministers stated in the Prague Communiqué (2001) ${ }^{12}$ that "in the future Europe, built upon a knowledge-based society and economy, LLL strategies are necessary to face the challenges of competitiveness and the use of new technologies, and to improve social cohesion, equal opportunities and the quality of life".

- The social dimension has been high on the agenda for quite some time, with the aim that "the student body entering, participating and completing higher education at all levels should reflect the diversity of Europe's population" (London Communiqué, May 2007'13). In the same communiqué, the Ministers reaffirmed the "importance of students being able to complete their studies without obstacles related to their social and economic background" and committed to continue their efforts "to provide adequate student services...and to widen participation at all levels on the basis of equal opportunity".

- Employability is also one of the main objectives of the Bologna process. In the London Communiqué (May 2007), ${ }^{14}$ the Ministers defined it as "the ability to gain initial employment, to maintain employment, and to be able to move around within the labour market". They went on to say that "each cycle of higher education should be relevant to the labour market" and that "further dialogue is needed between public and private employers, students, academics, higher education institutions and governments..."

- The attractiveness and competitiveness of European higher education in the world (Prague Communiqué, 2001 ${ }^{15}$ ), was emphasized by the Ministers since the very start of the Bologna process. Later on, this led to a call on European Higher education institutions "to further

12 "Towards the European Higher Education Area. Communiqué of the meeting of the European Ministers in charge of Higher Education" (Prague, 19 May 2001), http://www .ehea. info/Upload/document/ministerial_declarations/2001_Prague_Communique_ English_553442.pdf.

13 "Towards the European Higher Education Area: responding to challenges in a globalised world. London Communiqué, 18 May 2007," http://www.ehea.info/Upload/ document/ministerial_declarations/2007_London_Communique_English_588697.pdf.

${ }^{14}$ Ibid.

15 "Towards the European Higher Education Area. Communiqué of the meeting of the European Ministers in charge of Higher Education" (Prague, 19 May 2001), http://www .ehea. info/Upload/document/ministerial_declarations/2001_Prague_Communique_ English_553442.pdf. 
internationalize their activities and to engage in global collaboration for sustainable development" (Leuven Communiqué, 2009 ${ }^{16}$ ). In the Budapest-Vienna Declaration (March 2010), moreover, the Ministers stated they looked forward "to intensifying their policy dialogue and cooperation with partners across the world" ${ }^{17}$

In fact, since 2005 the Ministers have viewed the EHEA as "a partner of other higher education systems in other parts of the world, for balanced student and staff exchanges and cooperation between HE institutions" (Bergen Communiqué18). A strategy called "European Higher Education in a Global Setting" 19 was adopted by the Ministers at the London conference (2007) and the first Bologna Policy Forum was organized in conjunction with it, where representatives of higher education systems from other regions of the world were invited to discuss issues of mutual interest. This dialogue continued in the following years and all Ministerial meetings have featured a Bologna Policy Forum since then, up to the fifth one held in Paris in 2018. It is planned that the next Ministerial Conference in Rome 2020 the Forum will be a 'Global' one.

Undoubtedly, steering national policies towards common goals in each country has contributed to creating more homogeneous learning environments in the EHEA, facilitating cooperation and exchanges among institutions.

\section{II.4. Transparency tools}

The so-called transparency tools adopted by the Ministers are also distinctive features of the EHEA, playing a major role in the mobility of students and graduates.

16 "The Bologna Process 2020: The European higher Education Area in the new decade. Communiqué of the Conference of European Ministers Responsible for Higher Education" (Leuven and Louvain-la-Neuve, 28-29 April 2009), http://www.ehea.info/Upload/document/ ministerial_declarations/Leuven_Louvain_la_Neuve_Communique_April_2009_595061.pdf.

17 "Budapest-Vienna Declaration on the European Higher Education Area" (12 March 2010), http://www.ehea.info/media.ehea.info/file/2010_Budapest_Vienna/64/0/BudapestVienna_Declaration_598640.pdf.

18 "The European Higher Education Area- Achieving the Goals - Communiqué of the Conference of European Ministers Responsible for Higher Education" (Bergen, 19-20 May 2005), http://www.ehea.info/Upload/document/ministerial_declarations/2005_Bergen_ Communique_english_580520.pdf.

19 "European Higher Education in a Global Setting: A Strategy" (Norwegian Ministry of Education and Research, 2007), http://www.ehea.info/media.ehea.info/file/EHEA_in_a_ Global_Context/24/2/Strategy_plus_possible_actions_597242.pdf. 
- The widespread use of the Diploma Supplement (DS), originally developed by the European Commission, the Council of Europe and UNESCO, was one of the objectives of the Bologna Declaration. Basically, the DS is an agreed template for the description of qualifications in two languages - a widely used language in addition to the local one - with details on the higher education institution and the programme of study awarding it, which makes qualifications from different countries both understandable and comparable. A recently revised version of the DS template, and of the guidelines ${ }^{20}$ for implementing it, was formally adopted by the Ministers in 2018 (Paris Communiqué ${ }^{21}$ ).

- The outline of the ECTS Course Catalogue 22 is another agreed template for the description of institutions, programmes of study and single educational units that makes diverse educational environments more easily understandable and comparable. The items to be described are grouped in homogeneous sections, and the required information should be provided in at least two languages. The formal adoption of the revised ECTS Users' Guide by the Ministers in 2015 made the production of the Course Catalogue more stringent for European institutions. Moreover, the Heads of institution who sign the European Charter for Higher Education (ECHE) in order to participate in the Erasmus+ programme commit themselves to provide it for their partners.

- The production of Grade distribution tables ${ }^{23}$ for all programmes of study is illustrated in the ECTS Users' Guide and is also required for participation in the Erasmus+ programme. The tables are based on a statistical approach - illustrated in the ECTS Guide - which makes possible a fair conversion of the grades awarded to students in other countries/institutions/ programmes.

In the case of transparency tools, EU cooperation programmes and EHEA convergence actions clearly run in parallel and positively reinforce each other.

20 “Diploma Supplement” (Revised version, 2018), http://www.ehea.info/media.ehea.info/ file/20180205-06-Sofia/73/5/BFUG_BG_SR_58_4h_AG4_DS_ExplanatoryNotesRev_887735. pdf.

21 "Paris Communiqué" (Paris, 25 May 2018), http://www.ehea.info/Upload/document/ ministerial_declarations/EHEAParis2018_Communique_final_952771.pdf

22 "ECTS Users' Guide" (Publications of the European Union, 2015), https://ec.europa. eu/education/ects/users-guide/docs/ects-users-guide_en.pdf.

${ }^{23}$ Ibid. 
Although the conceptual thread followed so far in the construction of the EHEA is based on Ministers' official documents, it is essential to remember that the stakeholders' associations sitting in the BFUG as consultative members also provided substantial contributions, either as original input or in response to such documents.

- The European University Association (EUA) - now representing universities and national Rectors' Conferences in 48 countries - soon after the Bologna meeting and further to the merging of the Liaison Committee of European Union Rectors' Conferences with the Conférence des Recteurs Européens (CRE), showed its willingness to take an active role in the development of the European Higher Education Area, while reaffirming the basic principles of institutional autonomy and responsibility and asking the governments for the necessary support to engage in the required reforms. This responsible attitude was appreciated by the Ministers, who recognized the importance of higher education institutions in the Bologna process. Already in the Prague Communiqué (2001) they said that "the involvement of Universities and other Higher Education Institutions [...] as competent, active and constructive partners in the establishment and shaping of a European Higher Education Area is needed and welcomed" ${ }^{24}$ Another contribution from EUA are its regular Trends ${ }^{25}$ reports, based on surveys carried out in universities and presenting the institutional views on the implementation of the convergence process.

- The European Students'Unions (ESU) - umbrella organization of 45 national students' unions from 39 countries - developed well thoughtout policy papers on the main issues discussed in the process, such as mobility and internationalization, quality of higher education, public responsibility, governance and financing, and the social dimension of higher education. ESU also produces a report called Bologna with Student Eyes,${ }^{26}$ which is a reality-check of what has been agreed upon

24 "Towards the European Higher Education Area. Communiqué of the meeting of the European Ministers in charge of Higher Education (Prague, 19 May 2001), http://www.ehea. info/Upload/document/ministerial_declarations/2001_Prague_Communique_ English_553442.pdf.

${ }_{25}$ Gaebel Michael and Thérèse Zhang, "Trends 2018: Learning and teaching in the European Higher Education Area, 2018," https://eua.eu/resources/publications/757:trends2018-learning-and-teaching-in-the-european-higher-education-area.html.

${ }^{26}$ European Students Union (ESU), "Bologna with Student Eyes: The final countdown" (Brussels, May 2018), https://www.esu-online.org/wp-content/uploads/2019/02/BWSE-2018_ 
by national governments on the one hand, and what the actual situation is for students on the other, providing stimulating remarks from the student side on the state of reforms in the participating countries.

- EURASHE - representing professional higher education institutions also contributed relevant policy papers, analytical studies and other documents. Besides disseminating information, it plays an active role in organizing networking activities, learning events, conferences and seminars for the members and partners.

\section{Change}

The convergence process - of which the Ministers' Declarations and communiqués are the milestones - gave rise and continues to give rise to visible changes in national educational structures, as the formal commitments made by the Ministers have triggered a number of structural reforms. Several countries adopted new legislation following Bologna lines and introduced a three-tier degree structure, either replacing the old one-tier one or parallel to it; while other countries just strengthened their existing two-tier systems. All of them introduced an ECTS-based credit system, adopted the Diploma Supplement and implemented a quality assurance/accreditation system. In some cases, the reforms were introduced all at once, while in others a more gradual approach was adopted. The timing of structural reforms also varied greatly in the various countries, with some of them starting soon after the Bologna Declaration (like Italy) and others (like Spain) waiting until just before the EHEA was launched.

Italy provides an example of a comprehensive, radical reform of the higher education system along European lines. The new University $\mathrm{Law}^{27}$ was passed in November 1999, a few months after the Bologna Declaration (June 1999), and subsequently amended in 2004: the traditional Italian long study programmes were abolished in favour of a system based on a first cycle degree and a second cycle degree, followed by doctoral studies; an ECTS-based credit accumulation system was adopted nationally; and awarding the Diploma Supplement was made mandatory for all institutions. Moreover, financial incentives were made available to institutions to develop integrated programmes with European partners and to promote student mobility. The reform, whose

\footnotetext{
web_Pages.pdf.

27 “Italian Ministerial Decree No.509 (3 November, 1999)," http://www.miur.it/0006Me nu_C/0012Docume/0098Normat/2088Regola.htm.
} 
implementation started in the academic year 2001-2002, also gave institutions more curricular autonomy, and allowed them to be more creative in designing or redesigning their study programmes within the new European framework.

It should be mentioned here that Italy enacted the reform law based on the Bologna Declaration so rapidly because it was ready for it. Over the previous years, the country had become aware of the need to reform the existing higher education system, in order to solve old problems and meet new needs, as well as to align it with the other European systems. For this reason, the Italian Minister had been one of the four promoters of the Sorbonne meeting in 1998 and had volunteered to host a larger meeting in Bologna the year after. Consequently, the European common framework was promptly accepted and implemented by the Italian government, though not without hesitations and difficulty in the academic world, as the starting point for a necessary process of curricular innovation and European cooperation.

\section{After 20 years of change where does the EHEA stand now?}

Based on the last Implementation report presented by the BFUG, the implementation of the so called 'key commitments' - full adoption of the three-cycle structure and ECTS, of the Lisbon recognition convention and the Diploma supplement, and of a QA system based on the European standards and guidelines - is still uneven throughout the EHEA. As lack of compliance in some countries may be a serious challenge to the credibility of the whole area, a general implementation of the key commitments was urged by the Ministers last year in Paris and a structured peer-support approach was adopted, "based on solidarity, cooperation and mutual learning". ${ }^{28}$ Accordingly, a special Bologna Implementation Coordination Group (BICG) was formed, and has guided the formation of three thematic peer groups set up to focus on the three key commitments; peer-learning activities are being organized up to 2020 and beyond.

It is important to point out here that adopting new legislation or making any other type of reforms in the higher education system is only a first step in the implementation of the EHEA principles, actions and tools included in the key commitments. The second step is implementing them where education actually takes place: in institutions. In a report submitted to the Ministers in Yerevan, the BFUG showed its awareness that the first step "could be

28 "Paris Communiqué" (Paris, 25 May 2018), http://www.ehea.info/Upload/document/ ministerial_declarations/EHEAParis2018_Communique_final_952771.pdf. 
completed in a reasonable time and easily controlled" while "the second step, implementation at the grassroots level, requires a slow process of information and consensus-building in single institutions, departments and subject area, and is aimed at deeper cultural change,.... It takes more time and is more difficult to evaluate". ${ }^{29}$

Undoubtedly, most higher education institutions in Europe have undergone some sort of structural, curricular or organisational change throughout the Bologna process. This change has taken place with different degrees of involvement and consensus of academics, administrators and students and with different levels of human and financial resources for the achievement of their goals. Based on past experiences, some questions should now be asked.

First, to what extent have structural reforms really affected grassroots educational activities? In other words, even though all EHEA members have formally adopted a common degree structure and credit system, how deeply have their underlying principles - like student-centred learning - been implemented in actual programme design and everyday teaching/learning practice? How far has the agreed European QA framework succeeded in developing a widespread quality culture in single institutions and programmes of study? How extensively have the shared guidelines for the recognition of degrees and periods of study been applied to mobile students?

With particular reference to the key principle of student-centred learning, in Yerevan (2015) the Ministers reiterated their commitment to "encourage and support HE institutions and staff in promoting pedagogical innovation in student-centred learning environments....". ${ }^{30}$ Again, the questions are: to what extent has this commitment been translated into action in single EHEA countries? And has this action really produced positive pedagogical innovation in institutions?

It rather seems that this issue is seldom addressed openly and constructively in the interaction between ministries and institutions, simply because ministries and institutions often do not have the same goals nor do they speak the same language. The former are mainly concerned with legislation and the allocation of funds; they need objective facts and figures to include in their reports, and are satisfied with the outcomes of the external evaluations made by QA agencies. The latter operate in educational

29 "The Bologna Process Revisited: The Future of the European Higher Education Area" (Bfug report, Yerevan, 2015), http://www.ehea.info/media.ehea.info/file/2015_Yerevan/71/1/ Bologna_Process_Revisited_Future_of_the_EHEA_Final_613711.pdf.

30 "Yerevan Communiqué" (EHEA ministerial Conference, 14-15 May 2015), http://www. ehea.info/Upload/document/ministerial_declarations/YerevanCommuniqueFinal_613707.pdf. 
environments that are a conglomerate of individual teachers and individual students, and are shaped by different discipline-related cultures with their different underlying traditions.

Rightly, public administration is accustomed to planning, monitoring and evaluation, but these concepts cannot be automatically extended to higher education institutions. Planning is essential to define realistic educational objectives and to give the academic community a common sense of direction, but too much concentration on planning to reach predetermined objectives may severely hinder creativity and flexibility in teaching, while introducing an element of rigidity in the learning process which does not allow students to build on their individual learning styles and aspirations. Monitoring and evaluation are also important for institutions to become aware of what has actually taken place in a given teaching/learning environment and to enhance educational activities, but an articulated framework of external achievement-based evaluations, possibly affecting funding or reputation, may lead teachers and learners to formal compliance with the requirements rather than to the open trial-and-error approach that should guide innovative teaching/learning activities.

Suggestions for pedagogical innovation may be well received by academics as an eye-opener, if the new ideas are shared with peers and recognized as relevant to improve the quality of their professional and international activities, like teacher exchanges or joint degrees. Therefore, the strategies to facilitate the creation of student-centred learning environments in institutions should be mainly discussed by academics among themselves and/or with experts in the field. In the Trends 2018 survey EUA has found different approaches to teaching enhancement in universities in 43 European countries, with greater participation in voluntary (77\%) rather than compulsory (37\%) activities. It seems that university teachers do not like to be 'trained', but may be willing to take the opportunities offered to them for reflecting on the learning process and enhancing their teaching skills. Therefore, such opportunities should definitely be increased in institutions and teachers should be encouraged to participate, while governments should play their role by funding these institutional initiatives and giving greater relevance to teaching in academic careers. Insufficient actions in this area may be a serious challenge to the real implementation of the main underlying principle of the EHEA.

Furthermore, it should be mentioned that the institutional implementation of the transparency tools - that are a significant aspect of the key commitments - is also uneven in many countries. Although they are required by the EHEA and the EU, the Diploma Supplement, the ECTS course catalogue and grade distribution tables are not yet universally used: lack of expertise, costs and 
administrative burdens are often reported as being the major obstacles. Here again, there seems to be a gap between national requirements and field implementation in institutions. In some countries, initiatives of national coordination providing guidelines to institutions have somehow filled this gap, providing standard models and examples of good practice, or expert support for specific cases, thus limiting the efforts required of single institutions. Peer-learning activities at the EHEA level could provide opportunities for exchanging these national experiences and reaching out to institutions in more practical ways.

A second question to be asked here is: have EHEA principles, actions and tools been implemented consistently by European countries and institutions? According to the BFUG report (2015), "the original European vision ... has often been interpreted in different ways when used as leverage for national reforms", possibly because it "was not well communicated to or not well understood by all stakeholders in higher education and by other societal actors in the participating countries". ${ }^{31}$ This statement can be supported by two familiar examples concerning first cycle degrees and the ECTS credit system

In the case of the first cycle of study, the Bologna Declaration states that the degree awarded on completion of this cycle should be relevant to the labour market, but in the EHEA countries this principle is not always interpreted in the same way. Already at the beginning of the Bologna Process Guy Haug and Christian Tauch ${ }^{32}$ reported that in most countries more professionally oriented degrees offered by certain institutions in certain disciplines coexisted with more academic or scientific degrees offered by other institutions or in other disciplines, the general orientation being "not that first degrees should be just a preparation for a particular well-defined profession, but rather that certain dimensions required for nearly all future professional activities (transversal skills) should receive due attention". Therefore, they pointed out not only that the same principle is applied in different ways in different systems, institutions or disciplines, but also that a common denominator can always be found, if a basic principle is redefined in broader terms taking the diversity of institutions and disciplines into account.

31 "The Bologna Process Revisited: The Future of the European Higher Education Area" (Bfug report, Yerevan, 2015. http://www.ehea.info/media.ehea.info/file/2015_Yerevan/71/1/ Bologna_Process_Revisited_Future_of_the_EHEA_Final_613711.pdf.

${ }_{32}$ Haug Guy and Christian Tauch, "Trends in Learning Structures in Higher Education (II). Follow-up Report prepared for the Salamanca and Prague Conferences of March/May 2001" (April 2001), http://www.aic.lv/ace/ace_disk/Bologna/Reports/Trends/trend_II.pdf. 
The second example refers to the adoption of the ECTS-based credit system by European institutions. The system provides that 60 credits per year should be allocated to course units on the basis of the student workload required to achieve the learning objectives of each course. In some institutions/ disciplines, however, the allocation of credits is still affected by other factors, such as the role played by teaching hours or the perceived importance of a course, and there often is a tendency to focus more on workload than on learning outcomes. European institutions/disciplines should be made aware of these differences in the implementation of the basic principle, and a continuous exchange of good practice among academics should be promoted, to help them develop a common concept of credits that takes into account not only workload but also learning outcomes and teaching/learning methods.

Other similar examples could be provided. In general terms, it seems that inadequate coordination among institutions and academics in the EHEA countries may be a serious challenge to its success. In the past 20 years a common framework has been jointly defined by the ministers, it is now time for European academic communities - institutional leaders, teachers, researchers, administrative staff and students - to analyse the changes that have taken place in their institutions and compare interpretation and implementation trends. By working together they would be able to redefine or reorient the common principles whenever divergent interpretations and tendencies emerge. This was done for quite some time when the European Commission supported initiatives like Thematic networks, or a discipline-based project like "Tuning Educational Structures in Europe", not to mention the groups of European experts - like the ECTS/DS experts - who worked together to construct a common European credit system. Even when national groups of Bologna promoters were set up to work with institutions at the national level, they were given the opportunity to meet at the European level to exchange experiences and discuss specific issues of common interest. As these European initiatives have gradually faded away, the national dimension has taken over in the EHEA implementation process: the outcomes of international academic cooperation have been totally replaced by national implementation reports based on administrative information coming from the single ministries.

\section{Conclusions}

We believe that the goal of effective and consistent implementation of the European Higher Education Area can only be achieved through substantial involvement of the academic communities and greater collaboration among 
them across countries, institutions and disciplines. International academic cooperation has been going on for quite some time, but the context is now much more favourable, as a solid framework has been built by national governments and other major actors in higher education: common principles, structures, policies and tools are broadly accepted in 48 countries and major obstacles have been removed. We are confident that this shared vision and the wealth of mutual knowledge accumulated over the years have developed a sufficient critical mass to enable groups of academics, administrators and students from various European countries to successfully coordinate the efforts taking place at national and international level.

\section{Bibliography}

"Budapest-Vienna Declaration on the European Higher Education Area." March 12, 2010. http://www.ehea.info/media.ehea.info/file/2010_Budapest_Vienna/64/0/ Budapest-Vienna_Declaration_598640.pdf.

"Convention on the Recognition of Qualifications concerning Higher Education in the European Region.” Council of Europe, Lisbon, 11 April 1997. https://www. coe.int/en/web/conventions/full-list/-/conventions/rms/090000168007f2c7.

"Diploma Supplement." Revised version, 2018. http://www.ehea.info/media.ehea. info/file/20180205-06-Sofia/73/5/BFUG_BG_SR_58_4h_AG4_DS ExplanatoryNotesRev_887735.pdf.

“ECTS Users' Guide.” Publications of the European Union, 2015. https://ec.europa. eu/education/ects/users-guide/docs/ects-users-guide_en.pdf.

"European Higher Education in a Global Setting: A Strategy." Norwegian Ministry of Education and Research, 2007. http://www.ehea.info/media.ehea.info/file/ EHEA_in_a_Global_Context/24/2/Strategy_plus_possible_actions_597242. pdf.

"Italian Ministerial Decree No.509 (3 November, 1999)." http://www.miur.it/0006M enu_C/0012Docume/0098Normat/2088Regola.htm.

"Joint declaration on harmonisation of the architecture of the European higher education system." Paris, the Sorbonne, 25 May 1998. http://www.ehea.info/ media.ehea.info/file/1998_Sorbonne/61/2/1998_Sorbonne_Declaration_ English_552612.pdf.

"Paris Communiqué." Paris, 25 May 25 2018 . http://www.ehea.info/Upload/ document/ministerial_declarations/EHEAParis2018_Communique_ final_952771.pdf.

"Realising the European Higher Education Area. Communiqué of the Conference of Ministers responsible for Higher Education.” Berlin, 19 September. $2003 \mathrm{http} / /$ www.ehea.info/Upload/document/ministerial_declarations/2003_Berlin_ Communique_English_577284.pdf. 
"Standards and Guidelines for Quality Assurance in the European Higher Education Area (ESG).” Brussels, Belgium, 2015. https://enqa.eu/wp-content/ uploads/2015/11/ESG_2015.pdf.

"The Bologna Process 2020: The European higher Education Area in the new decade - Communiqué of the Conference of European Ministers Responsible for Higher Education.", Leuven and Louvain-la-Neuve, 28-29 April 2009. http://www. ehea.info/Upload/document/ministerial_declarations/Leuven_Louvain_la_ Neuve_Communique_April_2009_595061.pdf.

"The Bologna Process Revisited: The Future of the European Higher Education Area." Bfug report, Yerevan, 2015.

"The European Higher Education Area - Achieving the Goals. Communiqué of the Conference of European Ministers Responsible for Higher Education." Bergen, 19-20 May 2005. http://www.ehea.info/Upload/document/ministerial_ declarations/2005_Bergen_Communique_english_580520.pdf.

"The European Higher Education Area: The Bologna Declaration." 19 June 1999. http://www.ehea.info/Upload/document/ministerial_declarations/1999_ Bologna_Declaration_English_553028.pdf

"Towards the European Higher Education Area - Communique of the meeting of the European Ministers in charge of Higher Education.” Prague, 19 May 2001. http://www.ehea.info/Upload/document/ministerial_declarations/2001_Prague_ Communique_English_553442.pdf.

"Towards the European Higher Education Area: responding to challenges in a globalised world. London Communiqué.” 18 May 200.

"Yerevan Communiqué." EHEA ministerial Conference, 14-15 May 2015. http:// www.ehea.info/Upload/document/ministerial_declarations/ YerevanCommuniqueFinal_613707.pdf

Bologna Working Group on Qualifications Frameworks. "A Framework for Qualifications of the European Higher Education Area." Ministry of Science, Technology and Innovation, Copenhagen, 2005. http://ecahe.eu/w/ images/7/76/A_Framework_for_Qualifications_for_the_European_Higher_ Education_Area.pdf.

European Students Union (ESU). "Bologna with Student Eyes: The final countdown, Brussels.” May 2018. https://www.esu-online.org/wp-content/uploads/2019/02/ BWSE-2018_web_Pages.pdf.

Gaebel, Michael, and Thérèse Zhang. "Trends 2018: Learning and teaching in the European Higher Education Area." https://eua.eu/resources/publications/757: trends-2018-learning-and-teaching-in-the-european-higher-education-area. html.

Haug, Guy, and Christian Tauch. "Trends in Learning Structures in Higher Education (II). Follow-up Report prepared for the Salamanca and Prague Conferences of March/May 2001.” April 2001. http://www.aic.lv/ace/ace_disk/Bologna/ Reports/Trends/trend_II.pdf. http://www.ehea.info/media.ehea.info/file/2015_ Yerevan/71/1/Bologna_Process_Revisited_Future_of_the_EHEA_ 
Final_613711.pdf. http://www.ehea.info/Upload/document/ministerial_ declarations/2007_London_Communique_English_588697.pdf.

\section{About the author}

MARIA STICCHI DAMIANI (msticchi@gmail.com), is a former professor of English at the Free International University of Social Studies (LUISS) in Rome, where she served as Head of the Department of Modern Languages and Rector's delegate for International Relations. She was President of the European Association for International Education (EAIE) in 1992 and Erasmus prize for Italy in 1994. She was the Italian member of the Socrates/Erasmus SubCommittee and of the Erasmus Mundus Committee for many years. She was also member of the Management Committee of the European Project "Tuning Educational Structures in Europe" and international ECTS/DS counsellor, active in international projects worldwide. She acted as Italian representative in the Bologna Follow-Up Group (BFUG) until 2014 and coordinated the Italian team of Bologna Experts. She has published extensively both on language-related issues and on international education. 


\title{
From 1999 to 2019: 20 years of European debate, development, and achievements
}

\author{
Maria Sticchi Damiani
}

doi: http://dx.doi.org/10.18543/tjhe-6(2)-2019pp51-71

\section{Copyright}

Copyright for this article is retained by the Publisher. It is an Open Access material that is free for full online access, download, storage, distribution, and or reuse in any medium only for noncommercial purposes and in compliance with any applicable copyright legislation, without prior permission from the Publisher or the author(s). In any case, proper acknowledgement of the original publication source must be made and any changes to the original work must be indicated clearly and in a manner that does not suggest the author's and or Publisher's endorsement whatsoever. Any other use of its content in any medium or format, now known or developed in the future, requires prior written permission of the copyright holder. 